\title{
Editorial
}

\section{Respiratory Involvement in Guillain-Barre Syndrome: The Uncharted Road to Recovery}

Guillain-Barre syndrome (GBS) is one of the most common causes of acute flaccid quadriparesis with an incidence of $0.6-1.5 / 100,000$. It is also one of the most common causes of neuromuscular respiratory failure with $17 \%-30 \%$ patients requiring mechanical ventilation. ${ }^{[1]}$ Respiratory failure contributes to significant morbidity and mortality in patients with GBS and is linked to worsening of outcomes and long-term functional prognosis. ${ }^{[2]}$ Monitoring of lung function, anticipation of mechanical ventilation and pulmonary rehabilitation are important for optimal treatment and recovery of patients.

Respiratory compromise in GBS is linked to many factors. Upper airway compromise and weakness of pharyngeal and laryngeal muscles lead to difficulty in clearing of secretions and airway maintenance, thereby also increasing the chances of aspiration. The weakness of inspiratory and expiratory muscles of respiration leads to poor lung compliance, microatelectasis, hypoxemia, and increased risk of infections due to poor coughing ability. Pulmonary complications are also compounded by immobility, intensive unit stay and mechanical ventilation.

Many clinical, pulmonary, and electrophysiological parameters have been extensively studied to predict respiratory failure in patients with GBS, as timely ventilation may change the course and prognosis for the patient. Rapid disease progression, bilateral facial palsy, autonomic dysfunction, ${ }^{[3]}$ time from onset to admission $<7$ days, inability to cough/stand/flex the arms or head, and elevated liver enzymes ${ }^{[4]}$ are some of these predictors. Vital capacity $<60 \%$ of predicted ${ }^{[4]}$ or below $20 \mathrm{ml} / \mathrm{kg}$, maximum inspiratory pressure $<30 \mathrm{~cm}$ of $\mathrm{H}_{2} \mathrm{O}$ or maximum expiratory pressure $<40 \mathrm{~cm} \mathrm{H}_{2} \mathrm{O}$ also indicate imminent respiratory arrest. ${ }^{[1]}$ Single breath count is a simple clinical bedside parameter to monitor lung function. ${ }^{[5]}$ In addition, abnormal phrenic nerve conduction, abnormal diaphragmatic electromyography, ${ }^{[6]}$ and axonopathic GBS are electrophysiological indicators that further correlate with respiratory failure.

Long-term follow-up of patients has shown residual impairment in a sizable proportion of patients with regard to motor and sensory function and occurrence of pain, fatigue, decline in the quality of life, and overall functioning. Respiratory impairment in the acute phase has been found to be associated with long-lasting functional impairment. However, in a limited number of studies, lung function values have been shown to have steady improvement with almost complete recovery and no residual detectable impairment after 2 years of disease. ${ }^{[7,8]}$ The respiratory impairment in GBS in subacute phase and its serial measurements have been an infrequent subject for research.

The study published in the current issue titled, "Pulmonary involvement in patients with Guillain- Barré syndrome in sub-acute phase"[9] highlights the impairment in lung function after acute illness and attempts correlation with clinical parameters at presentation and outcome measures in subacute phase. Chest expansion has been found to be an easily measurable variable which is statistically related to pulmonary dysfunction. Certain other factors also show association although statistical significance has been difficult to establish. There are also certain limitations to the study. The study had a small number of patients, and certain correlations could not be drawn clearly. Other clinical (like single breath count) and radiological parameters could not be included. Comparison of pulmonary function tests in the acute and follow-up stage could be useful, along with comparisons with motor impairment at both stages. Nevertheless, the study establishes a lacuna in the knowledge about the recovery of pulmonary function in GBS which warrants inspection. Respiratory muscle rehabilitation must be started in conjunction with other therapy measures while taking care to avoid "overuse" and prevent paradoxical weakening.

\section{Acknowledgment}

The author would like to acknowledge Dr. Shilpa Kulkarni, Additional Professor, Department of Pediatric Neurosciences, Bai Jerbai Wadia Hospital for Children, Mumbai, for her valuable guidance and support.

\section{Meenal Garg}

Department of Pediatric Neurosciences, Bai Jerbai Wadia Hospital for Children, Mumbai, Maharashtra, India

Address for correspondence: Dr. Meenal Garg, Department of Pediatric Neurosciences, Bai Jerbai Wadia Hospital for Children, Parel, Mumbai - 400 012, Maharashtra, India. E-mail: docmeenal@gmail.com

\section{REFERENCES}

1. Lawn ND, Fletcher DD, Henderson RD, Wolter TD, Wijdicks EF. Anticipating mechanical ventilation in Guillain-Barré syndrome. Arch Neurol 2001;58:893-8.

2. Witsch J, Galldiks N, Bender A, Kollmar R, Bösel J, 
Hobohm C, et al. Long-term outcome in patients with GuillainBarré syndrome requiring mechanical ventilation. J Neurol 2013;260:1367-74.

3. Sharshar T, Chevret S, Bourdain F, Raphaël JC; French Cooperative Group on Plasma Exchange in Guillain-Barré Syndrome. Early predictors of mechanical ventilation in GuillainBarré syndrome. Crit Care Med 2003;31:278-83.

4. Sunderrajan EV, Davenport J. The Guillain-Barré syndrome: Pulmonary-neurologic correlations. Medicine (Baltimore) 1985;64:333-41.

5. Kannan Kanikannan MA, Durga P, Venigalla NK, Kandadai RM, Jabeen SA, Borgohain R. Simple bedside predictors of mechanical ventilation in patients with Guillain-Barre syndrome. J Crit Care 2014;29:219-23.

6. Zifko U, Chen R, Remtulla H, Hahn AF, Koopman W, Bolton CF. Respiratory electrophysiological studies in GuillainBarré syndrome. J Neurol Neurosurg Psychiatry 1996;60:191-4.

7. Forsberg A, Press R, Einarsson U, de Pedro-Cuesta J, Widén Holmqvist L; Swedish Epidemiological Study Group. Impairment in Guillain-Barré syndrome during the first 2 years after onset: A prospective study. J Neurol Sci 2004;227:131-8.

8. Cole GF, Matthew DJ. Prognosis in severe Guillain-Barré syndrome. Arch Dis Child 1987;62:288-91.
9. Khanna M, Rawat N, Gupta A, Nagappa M, Taly AB Rukmani MR, et al. Pulmonary involvement in patients with Guillain-Barré syndrome in sub-acute phase. J Neurosci Rural Pract 2017;8:412-6

This is an open access article distributed under the terms of the Creative Commons Attribution-NonCommercial-ShareAlike 3.0 License, which allows others to remix, tweak, and build upon the work non-commercially, as long as the author is credited and the new creations are licensed under the identical terms.

\begin{tabular}{|l|l|}
\hline \multicolumn{3}{c}{ Access this article online } \\
\hline Quick Response Code: & \multicolumn{1}{|c|}{ Website: } \\
& www.ruralneuropractice.com \\
& \\
&
\end{tabular}

How to cite this article: Garg M. Respiratory involvement in Guillain-Barre syndrome: The uncharted road to recovery. J Neurosci Rural Pract 2017;8:325-6. 